sciendo Zagreb International Review of Economics \& Business, Vol. 23, Special Conference Issue, pp. 73-90, 2020 (C) 2020 Faculty of Economics and Business, University of Zagreb and De Gruyter Open All rights reserved. Printed in Croatia ISSN 1331-5609; UDC: $33+65$

DOI: 10.2478 /zireb-2020-0024

CONFERENCE PAPER

\title{
The Applicability of Political Business Cycle Theories in Transition Economies
}

\author{
Aleksandra Praščević*
}

Abstract: The paper focuses the applicability of political cycles theories in specific circumstances of economies in transition which are at the same time the new democracies. Economic and political transition in these countries change both people's and politicians' preferences, institutions and generate specific politically motivated misuse of economic policymaking. Theories of political cycles in macroeconomics have been developed since 1970s, when the fact that policymakers could use economic policy as an efficient tool for increasing their chances for reelection became obvious. In countries with parliamentary democracies, incentives of policymakers to influence election results could be opportunistically motivated (opportunistic models) or ideologically motivated (partisan models). On the other side, voters could be naïve or rational, with different economic outcomes, as argued in extensive political cycles literature. The paper studies specific political motives of politicians in transition economies which are faced, especially in first fazes of transition with weak institutional mechanism and rules, and naïve voters. Consequently, opportunistic motives dominate ideological ones. The paper also focuses how the development of the institutional environment, especially in the context of international integration, such as accession to the European Union, reflects on the political business cycles in these countries.

Keywords: transition economies; political business cycles theories; institutions

JEL Classification: $\mathrm{P} 26, \mathrm{D} 72, \mathrm{E} 02$

\section{Introduction}

In parliamentary democracies the conventional analysis of macroeconomic policy assumes that economic policymakers are responsible for the country's economic performance, such as the inflation rate, unemployment rate, and economic growth rate. Political economy today considers the connection between economics and politics

\footnotetext{
*Aleksandra Praščević is at Faculty of Economics, University of Belgrade, Belgrade, Serbia
} 
using the methods of neoclassical economic analysis, rational choice, and game theory. Unlike in the traditional approach, in which the state is exogenous in macroeconomic models, political economy in the domain of macroeconomics, the so-called political macroeconomics or the new political macroeconomics, considers the government and its economic policy to be endogenous, assuming that economic policy is used to achieve both economic and political goals. This is precisely the focus in theories of political business cycles. Political macroeconomics connects economic policymakers' attempts to realize macroeconomic goals through economic policy with election cycles and their political motives.

If politics is generally defined as "deciding who gets what, when and how" (Lasswell 1958), then it is clear that theories of political cycles must include two components - economic and 'political' politics. The economic goals in the political business cycle models are a high economic growth rate, low unemployment rate, low inflation rate, and a certain income distribution. Opportunistic motives (to win elections) and partisan motives (to fulfil the party's economic program and partisan goals in the field of macroeconomic results that will improve the position of voters or sympathizers of certain parties) appear as political motives that determine the behavior of economic policymakers. In models of political cycles, the public, i.e., the voters, are given the opportunity to decide on the political prospects of economic policymakers, i.e., the politicians in power, based on their success in achieving macroeconomic goals (low inflation or unemployment rates, or high economic growth).

Theories of political cycles focus on the character and potential shortcomings of a democratic political system that can be misused. However, democracies have rules and institutional mechanisms. Therefore, institutions - defined as the rules of the game (North 1990, p.3) - that limit possible misuse of economic policy become important (an independent central bank and transparent monetary policy based on monetary rules, rules for conducting fiscal policy and the action of the fiscal council, etc.). Democratic institutions are designed to protect against tyranny and to help convert society's preferences into outcomes. In addition to institutions, the rationality of voters restricts misuse, as they can punish politicians who abuse economic policy by not re- electing them, thus deterring economic policymakers from abusing the system.

Theories of political business cycles have been developed for the conditions of parliamentary democracies as they exist in developed economies. In addition to the traditional sources of political business cycles, a very extensive literature considers various aspects of the democratic process and system on the one hand, and economic policy on the other. Thus, it considers the economic policy of coalition governments versus those led by majority governments, the greater propensity of coalition governments to run budget deficits, and the fact that budget policy cycles result more frequently from the misuse of fiscal policy than of monetary policy. Modern theories of political cycles examine the reasons why even in a situation where voters are rational and the political system is democratic, it is possible for economic policy to still be abused. 
Economies in transition, also called 'new democracies', became a special area of research in the theories and models of political cycles, due to the fact that the economic transition in these countries took place hand in hand with a new wave of democratization. The specifics of these countries were significant because the economic and political systems were changing at the same time, which is considered to be the biggest global institutional change in the recent past. The economic and political institutional changes were decisive for the success of the economic transition, as this paper will show. They also affected the possibility of politicians abusing economic policy, because the development of institutions limits such abuses. The construction of economic and democratic institutions in transition countries has also been examined in connection with their accession to the European Union and the standards imposed in the accession process. The transition countries that joined the EU were more successful in both changing their institutional framework and limiting the political abuse of economic policy.

The rest of this paper examines the context in which theories of political cycles emerged by focusing on the most important turning points in the theoretical and methodological development of macroeconomics. It then turns its attention to the application of the political cycle model in transition economies, focusing on the specific characteristics of voters and motives of economic policymakers. The importance of building economic and political institutions to limit abuse by politicians in power in transition countries is considered, as well as the factors that determine their creation.

\section{The development of political cycle theories in modern macroeconomics}

Political business cycle models have been important in macroeconomics since the 1970s, when it became clear that the idea of benevolent economic policymakers concerned exclusively with social welfare was unrealistic. After the Second World War the implementation of Keynesian economic policy, with its goal of establishing full employment and increasing social welfare through the active use of fiscal policy, meant that governments became an important factor in the functioning of the economic system. In 1943 Michal Kalecki formulated the concept of 'full-employment capitalism' in which the factor of labor gained in importance, reflecting the increased power of the working class and contributing to greater equity in the distribution of income between collective actors (social classes). However, when profits began to decline, wages rose above productivity growth, and production capacities recorded significant underutilization, with persistent and rising inflation, Keynes's theory and Keynesian economic policy were blamed. The recessions during the 1970s, atypical because they were accompanied by rising inflation, led to the abandonment of the Keynesian economic system and helped establish the dominance of neoliberal ideas in economic theory and politics, which persisted until the last Great Recession (2007-2009). 
From the 1970s, 'full-employment capitalism' was replaced by the radical anti-Keynesian conclusions of 'free-market macroeconomics' (Akerlof 2007, pp.6-7), which held an intellectual monopoly in macroeconomics that resulted in a lack of pluralism in macroeconomic ideas. The changes that took place in the dominant macroeconomic paradigm, first with the rise of monetarism and later with the New Classical macroeconomics based on the revolution of rational expectations, had a significant impact on the emergence and development of theories of political business cycles.

\section{Traditional political business cycle models}

The influence of modern macroeconomics was pervasive and went far beyond economic theory. First, the insistence on the mistakes of Keynesian economic policy showed that the real motives of the economic policymakers were primarily political. This encouraged the development of political cycle theories that directly link the results of political elections with economic results, an idea that had been present in earlier economic analysis (for example, Anthony Downs' famous book An Economic Theory of Democracy (1957), or the above mentioned paper by Polish economist Michal Kalecki, Political Aspects of Full Employment (1943)). However, by the 1970s government had played an active role in the economy for decades, and there had been episodes in which economic policy was abused in pre-election periods to improve economic performance in order to win elections. In 1975 Nordhaus formalized the first model of political business cycles in order to explain episodes in which President Nixon had misused economic policy. The Nordhaus model, together with the models of Lindbeck (1976) and Tufte (1978), belongs to the traditional opportunistic political business cycle model in which opportunistically motivated politicians (policymakers) face naive voters whose expectations are adaptive. In order to be reelected, governments that are driven by private interests exploit the short-run Philips curve and naive voters whose expectations are adaptive by generating a decrease in the unemployment rate just before an election, at the cost of a rising inflation rate after the election. Thus, inflation and unemployment are subject to cyclical fluctuations that follow the election cycle.

In the 1970 s, changes in economic theory and policy had another important impact on the development of political cycle theory. The doctrinal reasons for abandoning Keynesianism and returning to liberal and neoliberal ideas resulted in the definitive abandonment of the concept of full-employment capitalism. The rise of neoliberal ideas from the 1970 s was associated with global political changes and the ascendancy of right-wing and conservative parties. Since then, political cycle theories have focused on political-partisan issues. According to the partisan political cycle model, because party ideologies differ there are ideological differences regarding macroeconomic goals and issues such as inflation, unemployment, and economic 
growth. Thus, partisan motives are the most important political influence in macroeconomic policy. Hibbs (1977) created the first partisan model, dividing the political spectrum into left and right depending on incumbents' preferences regarding unemployment and inflation: left-wing governments prefer higher employment and economic growth, and right-wing governments are more interested in lower inflation with no regard for the unemployment rate ${ }^{1}$. Like the Nordhaus model, Hibbs's model exploits the short-run Philips curve, and incumbents face naïve voters who form adaptive expectations. Thus, Hibbs's model belongs to the traditional partisan political business cycle model.

\section{Rational political business cycle models}

The third important impact of the development of modern macroeconomics relates to changes in the theoretical and empirical macro model, and includes first adaptive and then rational expectations. This was a consequence of persistent and rising inflation, which imposed changes on the way wages and prices were formed. Dramatic changes in macroeconomic modeling involving expectations and the representative subject have also affected models of political cycles. In the neoliberal era successful economic policy was based on the mainstream macroeconomic consensus, a new neoclassical synthesis in which dynamic stochastic general equilibrium (DSGE) models were developed based on rational expectations, intertemporal choice, and new econometric methods. Thus, until the 2007-2009 crisis the macroeconomic mainstream was based on the microeconomic foundations of macroeconomics, the 'equilibrium' framework, and the hypothetical-deductive abstract approach ${ }^{2}$ to modeling individuals' behavior, which together determine both macroeconomic outcomes and macroeconomic trends (Praščević 2014, p.23).

The rational expectations revolution radically changed macroeconomic theory and modeling (Lucas 1976; Lucas and Sargent 1979), but it was equally important for the development of political business cycle models. In opportunistic models the voters were rational rather than naïve, which is why incumbents cannot exploit the shortrun Philips curve in order to systematically deceive voters with pre-election economic stimulation. Since then, rational opportunistic political business cycle models have been developed. Because the rationality of voters limits the possibility of pre-election manipulation, the models had to find other ways that voters could be deceived and introduced the assumption of asymmetric information, available to politicians in power on the one hand and to voters on the other. Asymmetry primarily refers to the competency of the government, which is defined in different ways: the ability to implement appropriate fiscal policy (Rogoff and Sibert 1988; Rogoff 1990), ensuring economic growth without inflation (Pearson and Tabellini 1990), or isolating the economy from accidental shocks (Cukierman and Melzer 1986). 
The rationality of voters has also been introduced into partisan political business cycle models. The Italian economist Alberto Alesina introduced systematic partisan differences regarding macroeconomic goals and policies into models with rational expectations in which voters prefer the policies of left-wing or right-wing parties (Alesina 1987, 1988, 1989; Alesina and Sachs 1988; Alesina and Rosenthal 1995). Thus, politicians wanting to address centrist voters can abandon their original ideology and change their macroeconomic goals over the electoral cycle in order to increase their prospects of reelection. In this way electoral uncertainty has real effects on macroeconomic policy and outcomes, inducing macroeconomic instability. In the world of rational expectations only unexpected inflationary/deflationary shocks have real effects, which may be a consequence of electoral uncertainty that can cause shocks with temporary real macroeconomic effects. However, although partisan political motives do not result in systematic cycles of macroeconomic variables, there is a correlation between political and institutional stability and the country's economic indicators: greater instability and polarization are associated with poor economic indicators (high inflation and unemployment rates). Thus, empirical results have significant normative implications that are related to the conduct of economic policy on the basis of rules rather than discretionary powers, institutional change (introducing an independent central bank and fiscal council), and coordination of economic policy.

\section{Political cycles in monetary and fiscal policy}

In addition to distinguishing opportunistic and partisan political business cycles, there is a difference between models that focus on monetary policy misuse and those that analyze fiscal policy misuse. If the focus is on monetary policy, then the analysis must become more complex by including an institutional framework for the relationship between politicians and an independent or semi-independent central bank (Rogoff 1985; Alesina and Sachs 1988; Waller 1992; Alesina and Summers 1993; Persson and Tabellini 1994; Alesina and Gatti 1995; Walsh 1995; Svensson 1995; Alesina, Roubini, and Cohen 1997).

As changes in the institutional mechanisms of monetary policy have reduced the possibility of monetary policy misuse, as central banks have become more independent globally, political budget cycle (PBC) models have become more important. These models analyze the relationship between the electoral cycle and fiscal policy, including the following issues: whether budget deficits are higher in pre-electoral periods, whether manipulation of the budget is an effective tool for gaining votes, what the role of partisan politics is in framing fiscal policymaking (differences between left-wing and right-wing parties regarding their fiscal priorities - the levels and structure of public expenditure and the size of budget deficits), whether budget deficits depend on the type of government (coalition, majority, or presidental), and 
whether the political budget cycles are more important phenomena in transition and developing economies than in advanced economies (Akhmedov and Zhuravskaya 2004; Brender and Drazen 2005; Shi and Svensson 2002, 2006; Klašnja 2008). The political budget cycle models explain misuse of fiscal policy within the framework of asymmetric information regarding government competence (Rogoff and Sibert 1988; Rogoff 1990; Drazen and Eslava 2005, 2006), public debt as a strategic variable (Alesina and Tabellini 1990; Persson and Svensson 1989), and fiscal illusion and distributional conflict (Alesina and Drazen 1991).

\section{The political economy of transition: facts and impact on political cycle theories}

Economic transition began in the 1990s in socialist countries with centrally planned economic systems and in countries of the former Social Federal Republic of Yugoslavia with a specific form of self-governing socialism. It was a wide-ranging process of transformation of a command economic system into a market economy, and of a one-party political system into a democratic system of parliamentary democracy (a type of polyarchy). Thus, in the following decades this group of countries, otherwise extremely heterogeneous, became not only a group of 'transition' economies, but also 'new democracies' characterized by transitional political systems with the characteristics of both unconsolidated democracies and semi-democratic systems. These countries implemented economic and political reforms at different speeds and achieved different results in building a market economic system (measured by indicators of transitional progress) and political democracy (consolidation of the democratic system). Therefore, some of them successfully completed these processes, becoming members of the European Union, while others remain 'stuck' in these processes with unfinished economic transformation and as semi- consolidated or non-consolidated democracies.

The transition from state socialism to capitalism, which for most socialist countries started between 1989 and $1991^{3}$, could be defined as a specific kind of experiment in modern history affecting around 30 countries $^{4}$. The economic and political transformations have been equally important, since the beginning was marked by the collapse of the one-party political system.

At first the process of economic transition received a lot of support because people expected greater economic freedoms, such as decentralized decision-making arrangements and private- sector market transactions, and greater political freedoms, including human rights, which had been denied in previous decades. The expectation was that citizens would find it easier to accept the temporary worsening of their economic position in the first phases of the transition because they were being compensated with the desired human rights and political freedoms. However, economic transition proved to be both costly and painful for many citizens who witnessed an 
erosion of living standards and public services and high levels of poverty and inequality over a longer period of time. On the other hand, for certain interest groups and sections of society - mostly connected with the previous socialist economic and political elite - who were able to utilize their resources to participate in the privatization process, economic transition offered extraordinary opportunities for political and financial gain. This continues to be the case in countries that have neither successfully implemented and completed the economic transition nor developed a consolidated democratic system. In these countries the enthusiasm for economic reform has diminished, as has enthusiasm for building a democratic system and democratic institutions, leading many citizens to turn to non-democratic political forces that promise authoritarian rule to reduce their economic and social problems. These countries appear to be stuck in a process of unending economic transition, and the ideals of economic and political liberalism on which the economic transition was initially based have almost disappeared. These are the key reasons why countries in transition are lagging behind in both developing democracy and economic development.

This is why the interaction between politics and economics in the political economy of transition is so important. The literature in this area of research is vast and includes the politics of economic reforms, the captured state and corruption, rent-seeking activities of policymakers in transition economies, and specific institutional arrangements that reduce economic growth. This paper focuses specifically on the impact of economic transition on the existence of political business cycles.

\section{Speed and success of the economic transition}

Initially, there was a wide range of transition economies, from the successful Central European and Baltic States that completed the transition process, through the insufficiently successful countries of Southeast Europe, to the former Soviet Union and East Asian countries. According to the World Bank, countries that joined the European Union have finished transiting (the Czech Republic, Estonia, Hungary, Latvia, Lithuania, Poland, Slovakia, and Slovenia in the first-wave of accession on 1 May 2004; Bulgaria and Romania in the second-wave of accession on 1 January 2007; and finally Croatia, which joined the EU on 1 July 2013). The experiences of former socialist countries that have successfully acceded to EU membership and of the less advanced transition countries of the former Soviet Union, regarding both economic and political reforms and including the role of policymakers and public support, are timely and valuable for understanding the complexity of the transition processes.

In the beginning the direction of the economic transition was clear and was inseparably linked to the idea of economic and political liberalism (which are often mistakenly identified). The doctrinal issues of the political economy of transition were based on the dictates of neoliberalism. Neoliberal ideology, specifically the Wash- 
ington Consensus, dominated economic transition reforms, determining the content, stages of the process, and dynamics. Domination primarily refers to important elements of neoliberal microeconomic policies: privatization, deregulation, and market solutions, while in the field of macroeconomic policy, neoliberalism implied following strict rules in both monetary and fiscal policy, central bank independence, and the primary goal of low and stable inflation rates, while employment and economic activity, i.e., economic growth, were left to the operation of market forces. The literature of economic transition and international experts and economic policymakers have all neglected the importance of the institutional framework to transition economies.

At first, the process of economic transition appeared relatively simple, with citizens in transition countries supporting the building of an economically superior market system and a democratic political system. This process was approached as a kind of "social engineering" (Cerović 2012, p.1), with the elements and phases of implementation and even the dynamics being prescribed. The transition was implemented in former socialist countries with the help of international experts. However, this universal approach had many limitations, which to date have been neglected. Among them are the specific conditions of individual countries, their historical legacy, the size of their economies, the differing development of individual economic sectors and availability of natural resources (especially energy sources), and different cultures, specifically the political cultures that existed before and during the socialist period.

The group of transition economies was originally heterogeneous because their initial economic and political conditions were different. After three decades of transition this heterogeneity is even more obvious because of the different paths the political and economic reform has taken in each economy. Achieving the complex transition goals was not going to result from spontaneous market forces or a simple break with the previous one-party political system, but required a well- conceived program to build a new economic and political system. Three trajectories of transition reform could be observed in transition countries (Turley and Luke 2011, p.7). The first trajectory is that of the radical reforms in the Central European and Baltic countries, which were the most successful in achieving their goals, including accession to the European Union. The second trajectory is the gradual reforms implemented in Southeastern Europe and most former Soviet republics, most of which are still experiencing problems building democratic institutions and consolidating democracy: their economies are still in the process of economic transition, burdened by the corruption and rent-seeking activities of policymakers, bureaucrats, and businessmen. The third trajectory has been implemented in several former Soviet republics in which the old political and economic systems still exist: dictatorship, monopoly of one political party, state control of the economy, and public ownership of businesses.

In many transition countries, skepticism concerning the reforms appeared ten years after the transition started (Cerović 2012, p.361). Two factors determined whether the transition programs were successfully implemented in each country: 
how radical the measures adopted during transition were, and the initial conditions. More liberal political reforms had a positive effect on the reforms, while regional tensions were a factor hindering economic transition and economic progress. Over time, even more than radical reform, institutions were recognized as a particularly important factor influencing the effects and results of the transition process (Cerović 2012, p.364).

It turned out that the goals that incumbents set in each country were decisive for the success of the transition process, as well as a consensus as to the necessity of the whole society accepting and evenly sharing the costs of transition. Accession to the European Union emerged as another important factor. The goal of joining the EU made difficult reforms more acceptable and accession meant meeting accession criteria, involving the market economic system, political democracy, and relevant institutions. The success of reforms and the completion of transition were reflected in accession to the European Union. However, for their own opportunistic reasons, the creators of the transition process often prolonged the reforms or consciously implemented them inadequately, blaming various factors for their failure. In some transition countries structural changes mirrored political cycles so that in the pre-election period the intensity of reforms decreased, only to intensify in the post-election years (Jula 2008).

The specific characteristics of voters in transition countries, the semi-democratic political systems, and other political factors such as national or religious conflict all facilitated this kind of manipulation, especially in the Western Balkan region and parts of the former Soviet Union where regional conflicts are frequent.

\section{Specificities of voters and politicians in transition economies}

Incumbents in developed economies have opportunistic and partisan political motives and misuse fiscal and monetary economic policy in an attempt to get re-elected, and the same thing happens in transition economies. The specific economic and political systems of transition countries lead to questions regarding both the incumbents' motives and the specifics of the voters and political parties competing in elections. The next set of issues refers to underdeveloped institutional mechanisms related to monetary and fiscal policy and to both economic and 'political' politics. These institutional issues became very important in the implementation of political business cycle models (Jakšić and Praščević 2010).

The claim that elections are won or lost depending on the economic results of the government is confirmed in developed countries, and in transition countries it includes dimensions concerning the success of the transition process itself; i.e., public support for and commitment to the transition process. The analysis is complicated because the heterogeneous countries in the group of transition economies followed different paths, with different goals and varying success. The dynamics of the process of economic and political transition made the complexity even greater: some of 
the characteristics present in the first phases of transition do not remain present in all countries in the following phases because over time the successful countries begin to look like developed economies and consolidated democracies and the specifics of transitional societies disappear, while in others countries they still persist today, after three decades of transition.

The specifics of applying the political business cycle model, at least in the early stages of transition, can be summarized as follows:

1. The specific motives of incumbents in transition countries differ from those in developed countries.

2. Voters in transition countries have insufficient knowledge about the market economy system, democratic procedures, and political democracy.

The specific motives of incumbents refer to the structure of the political process and political parties in transition countries. Political parties in these countries do not have a clear ideological profile or program, nor an active and stable partisan membership. This provides many more opportunities for party leaders to influence and change partisan policy with the primary opportunistic motive of staying in or coming to power, especially in a proportional electoral system in which post-election coalitions are very likely.

In transition countries such unprofiled political parties face voters who are unfamiliar with the functioning of the new political system. The transition implies the withdrawal of the state as an active actor in the economic system, but sooner or later the question arises as to the degree of state influence and interference in the economic sphere that is still necessary. This question concerns ideological differences between political parties, as well as the voters' ideological preferences.

\section{Opportunistic and partisan motives in transition economies}

The behavior of incumbents is determined by opportunistic and partisan motives, which are also present in the case of countries in transition. The incentives are also basically the same - to be re-elected and to accomplish certain ideological/partisan goals. However, in transition countries the opportunistic motive is not only to hold political power but also to be in a position to undertake rent-seeking activities, which in developed economies are limited by the institutional framework.

In the first phase of transition, incumbents' opportunistically motivated behavior was limited by macroeconomic problems in the form of high inflation, which was so serious that stimulating economic activity in order to win election was unlikely. The first stages of the transition process imposed high inflation and unemployment rates, which were to be solved using macroeconomic stabilization programs that induced a transitional recession and a large fall in GDP. This reduced voter support for the reform program from citizens who had little trust in political parties, government, 
parliament, or even foreign economic experts. Thus, incumbents could lose re- election, while decreased support for the economic and political reforms resulted in a reversal to a less democratic system and the functioning of the former economic system. Therefore, pre- election stimulation of the economy, using primarily fiscal policy, was tolerated in countries in transition because it kept pro-reform political forces in power - for example, in Serbia after Milošević was overthrown in October 2000. Opportunistically motivated behavior by public authorities was justified, especially if the country was extremely politically polarized and there were significant differences in economic and political priorities and the parties' goals, or when there was significant uncertainty about the election winner. Officials in transition countries depend on voters who are not always aware of the benefits or the necessity of transition processes and economic reforms.

During the first decade of transition the reforms were successful in the countries that had less polarized electorates and political parties. For this it was necessary to have a social consensus regarding the economic and political future of the country, which was often associated with foreign support in the form of possible accession to the European Union. The first transition countries that joined the European Union in 2004 experienced no significant political polarization, no reversals in economic policy, and no indecision as to the direction in which the country should go.

Although during the first phase of transition the voters in transition countries could be characterized as naïve and ripe for manipulation by policymakers, they learned quickly. As a result, the traditional model of opportunistic and partisan political cycles very quickly ceased to adequately analyze developments in transition economies. Rational opportunistic models began to gain in importance, such as those that focus on the problem of government competence regarding fiscal policy due to information asymmetry (Rogoff and Sibert 1988; Rogoff 1990).

Similarly, in transition countries ideological differences between parties of the left and right are specific and different to those in advanced economies and democratic countries. During the first phases of the transition, parties dominated that advocated - at least declaratively - significant political and economic reforms, with rapid privatization and the denial of any need for government intervention in the economy. Often, such ideas were tied to right-wing parties that promoted neoliberal economic ideas along with a nationalistic agenda, especially in countries where there were ethnic tensions. In the first phase the left-wing parties withdrew or, more precisely, took time to consolidate, because leftist ideas were connected with the earlier communist political system. Often, the different economic goals of political parties in transition countries came down to differences between pro-reform and counter-reform parties. In that case, as before, the opportunistic motives corresponded to a great extent with the model of rational partisan cycles (Alesina 1989; Alesina, Roubini, and Cohen 1997).

If there are significant ideological differences between the parties competing in elections, the issue of electoral uncertainty becomes especially important. It is also 
necessary to integrate opportunistic and partisan motives into the models applied to transition economies. With the interaction of partisan and opportunist motives, both left and right-wing parties are trying to get closer to the so-called median voter, which becomes more important as the transition nears its end.

\section{Dominance of budgetary political cycles in transition economies}

In transition economies the central bank, as the key monetary institution, plays an important role in economic policy. The central bank should prevent both partisan and opportunistic political motives from influencing monetary policy in order to ensure its credibility and reduce uncertainty, which may be encouraged by the imperfect information available to economic agents and significant political instability and polarization. Some of these characteristics are present in democratic countries, where economic data shows that partisan differences in conducting monetary policy are stronger than opportunistically motivated manipulation (Alesina, Roubini, and Cohen 1997). The existence of partisan differences in the rate of monetary growth and the level of short-term and long-term interest rates is consistent with the rational-partisan model of political cycles.

In order to eliminate the abuse of monetary policy, many transition economies have imposed institutional restrictions, primarily in the form of an independent central bank, leading to higher independence indices than in developed economies. This is especially true for the successful transition economies. Empirical evidence in the period 1990-1999 for the 10 Eastern European accession countries (Bulgaria, the Czech Republic, Estonia, Hungary, Latvia, Lithuania, Poland, Romania, Slovakia, and Slovenia) shows monetary political business cycles where the exchange rate is flexible and the central bank is dependent on the government. When the exchange rate is fixed and central bank is indepedent, incumbents misuse fiscal policy shortly before elections (Hallerberg and Souza 2000).

Incumbents attempting to artificially improve economic results in the pre-election period can use fiscal policy to redistribute income and improve the position of certain segments of society in accordance with incumbents' partisan/ideological interests or opportunistic motives. The type of political cycle based on the relationship between the election cycle and fiscal policy is called a political budget cycle, and has been the subject of analyses of both groups of transition economies and specific countries (Hallerberg and Souza 2000; Treisman and Gimpelson 2001; Akhmedov and Zhuravskaya 2004; Klašnja 2008; Lami and Imami 2014).

Political budget cycles are more present in underdeveloped economies and new democracies than in developed economies and democratic countries (Brender and Drazen 2005) because the political system is underdeveloped, voters do not understand how it functions, and the politicians have specific motives when conducting 
fiscal policy. Therefore, in the initial period of democratization voters are unable to make relevant choices; i.e., they are unable to anticipate the effects of expansive pre-election fiscal policy. They may be myopically oriented to the present and do not understand that the incumbents are accountable for macroeconomic outcomes over entire electoral periods. In that case politicians feel free to deceive with fiscal expansion and do not fear significant punishment because by winning the election they will secure their position in power. In the post-election period they will probably conduct restrictive policy, but again without fearing for their survival in power as the voters are myopically oriented. The political institutional environment in these countries gives incumbents the opportunity to make significant profit or rent by staying in power, so they are motivated to manipulate voters in every possible way in the pre-election period (Shi and Svensson 2006).

As voters in these countries get wise to politicians' characteristics and motives and become aware of the negative consequences of fiscal deficit, they become more fiscally conservative, similar to people in developed economies. In those circumstances government expenditure, i.e., revenue, is fiscally manipulated to no longer represent the total amount of the budget deficit: the structure is connected to the government's competence to improve economic performance without causing a budget deficit. Election-year government expenditure shifts towards more visible current consumption at the expense of reducing government investment, just as the rational opportunistic models assume (Rogoff and Sibert 1988; Rogoff 1990). The success of such manipulation depends on the existence of asymmetric information, which is connected to the state of democracy in a specific country. Empirical research from the former Soviet Union countries confirms such manipulation, especially in those countries that are partly democratic. In the most democratic former Soviet Union countries, the Baltic states, the degree of budget manipulation is lower, and in the least democratic countries (e.g., Tajikistan) only negligible changes could be found in budget expenditure in the pre-electoral period, due to the fact that the incumbents have complete control over the election institutions so the opposition party cannot win: the incumbents do not need to manipulate government expenditure since the regime is autocratic (Faychuk 2003). Such findings correspond with results showing that the magnitude of manipulation depends on the incumbent's probability of winning the election - the higher the probability, the less the manipulation (Faychuk 2003).

The specifics of the political budget cycle model in transition countries are also related to the possibility of using revenue from the privatization of public assets for fiscal expansion in the pre- election period. Episodes of misuse of privatization revenue for fiscal manipulation of expenditure exist in Albania (Imami, Lami, \& Kächelein 2011) and Serbia (Praščević 2012) where privatization policies have been observed to fluctuate according to electoral and partisan cycles. Right-wing governments tend to privatise to a greater extent than governments with other ideologies due to a partisan 
motive, and privatization will intensify before the election takes place, precisely in order to generate revenue that can finance increased government expenditure.

In the transition countries a lack of voter information becomes especially significant due to restrictions on media freedom, which make it even more difficult for voters to obtain appropriate information relevant to the elections. These constraints are present in semi-democratic transition economies that allow voters to be deceived about policy measures. Indices that measure media freedom differ; however, they consider the freedom of traditional media, which continue to play an important role in restraining politicians, but also social media and internet access, which could help to enforce rules and accountability.

\section{Conclusion}

Theories of political business cycles assume that political elections are won or lost depending on the economic results that voters observe in the pre-election period. This encourages policymakers to misuse economic policy in order to improve their re-election prospects by making macroeconomic performance in the pre-election period better than it really is. Whether economic policymakers are able to do so depends primarily on the institutional arrangements that form the framework for conducting monetary and fiscal economic policy, and also on the characteristics of voters (naive or rational) and on characteristics of the political system. The elements of political business cycles can be found in transition economies where incumbents often misuse economic policy in order to artificially improve economic outcomes, rather than undertaking more extensive and radical reforms. The specific characteristics of voters and of political parties, a semi-democratic political system, and undeveloped market economy institutional mechanisms contribute to politicians in power significantly and frequently misusing economic policy. Fiscal policy is manipulated more often than monetary policy, and models developed for transition countries should be based on the integration of both opportunistic and partisan motives. With the end of the economic transition and the building of a democratic system, the political business cycles in these countries become similar to those in developed economies. 


\section{ENDNOTES}

${ }^{1}$ Ten years after his first model, Hibbs presented empirical evidence that US Democrats are more averse to unemployment than Republicans, and vice versa for the inflation rate (Hibbs 1987, p.227). The reason is very simple: parties represent the interests of different voters and social classes (lower-income workers have the most to lose from unemployment and upper-income groups have more to lose from the distributional consequences of high inflation).

${ }^{2}$ As opposed to the historical-deductive method adopted by classical and Keynesian economists. The Keynesian revolution was a revolution in method; the same is the true for the rational expectations revolution and the rise of both New Classical Macroeconomics and New Keynesianism.

${ }^{3}$ Between the fall of Berlin Wall on 9 November 1989 and the collapse of the Soviet Union on 26 December 1991.

${ }^{4}$ Including former Soviet or Eastern Bloc countries and China, with certain specifics.

\section{REFERENCES}

Akerlof, G. A. (2007) The Missing Motivation in Macroeconomics, American Economic Review, 97(1), 5-36

Akhmedov, A.; Zhuravskaya, E. (2004), Opportunistic Political Cycles: Test in a Young Democracy Setting, The Quarterly Journal of Economics, 119 (4), 1301-1338

Alesina A.; Summers, L. (1993) Central Bank Independence and Macroeconomic Performance: Some Comparative Evidence, Journal of Money, Credit and Banking, 25(2), 151-162

Alesina A.; Tabellini, G. (1990) A Positive Deficits of Fiscal Deficits and Government Debt, Review of Economic Studies, 57, 403 - 414

Alesina, A. (1987) Macroeconomic Policy in a Two-Party System as a Repeated Game, The Quarterly Journal of Economics, 102, 651-78

Alesina, A. (1988) Credibility and Policy Convergence in a Two-Party System with Rational Voters, American Economic Review, 78 (4), 796-805

Alesina, A., (1989) Politics and business cycles in industrial democracies, Economic Policy, 8, 55-98

Alesina, A.; Sachs, J. (1988) Political Parties and the Business Cycle in the United States, 1948-1984, Journal of Money Credit and Banking, 20, 63-82.

Alesina, A.; Drazen, A. (1991) Why Stabilizations Delayed?, American Economic Review, 82, 1170 1188

Alesina, A.; Gatti, R. (1995) Independent Central Banks: Low Inflation at No Cost?, American Economic Review, 85(2), 196-200

Alesina, A.; Rosenthal, H. (1995) Partisan Politics, Divided Government and the Economy, Cambridge University Press, Cambridge

Alesina, A.; Roubini, N.; Cohen, G. D. (1997) Political Cycles and the Macroeconomy, MIT Press, Cambridge, Mass.

Brender, A.; Drazen, A. (2005) Political budget cycles in new versus established democracies, Journal of Monetary Economics, 52, 1271-1295

Cerović, B. (2012) Tranzicija - zamisli i ostvarenja, Ekonomski fakultet, Beograd

Cukierman, A.; Meltzer, A. (1986) A Positive Theory of Discretionary Policy, the Cost of Democratic Government, and the Benefits of a Constitution, Economic Inquiry, 24, 367- 388

Downs, A. (1957) An Economic Theory of Democracy, Harper Collins Publishers, New York 
Drazen, A. and Eslava, M. (2005) Electoral Manipulation via Expenditure Composition: Theory and Evidence, NBER working papers, 11085

Drazen, A., Eslava, M. (2006) Electoral manipulation via voter-friendly spending: Theory and evidence, University of Maryland, Manuscript

Faychuk, V. (2003) Political Budget Cycles in Transition Economies: Evidence from FSU Countries, thesis, https://kse.ua/wp-content/uploads/2019/02/Faychuk.pdf

Hallerberg, M.; de Souza, L. V. (2000), The Political Business Cycles of EU Accession Countries,

Hibbs, D. (1977) Political Parties and Macroeconomic Policy, American Political Science Review, 71 (4), 1467-1487

Hibbs, D. (1987) The American Political Economy, Harvard University Press, Cambridge, MA

Imami, D.; Lami, E.; Kächelein, H. (2011) Political cycles in income from privatization: The case of Albania, BERG Working Paper Series 77, Bamberg University, Bamberg Economic Research Group

Jakšić, M.; Praščević, A. (2010) Politička makroekonomija, Ekonomski fakultet, Beograd

Jula, D. (2008) Economic Impact of Political Cycles - The Relevance of European experinces for Romania, Working Papers of Institute for Economic Forecasting, 081101, Institute for Economic Forecasting

Kalecki, M. (1943) Political Aspects of Full-Employment, Political Quarterly, 14(4), 322-31

Klašnja, M. (2008) Electoral Rules, Forms of Government, and Political Budget Cycles in Transition Countries, Panoeconomicus, 55 (2), 185-218

Lami, E., Imami, D. (2014) Political Fiscal Cycles in Hungary, Contemporary Economics, 7, 73-98

Lasswell, H. D. (1958) Politics: Who Gets What, When and How, Meridian Books, Cleveland

Lindbeck, A. (1976) Stabilization Policies in Open Economies with Endogenous Politicians, American Economic Review Papers and Proceedings, 1-19

Lucas, R. (1976) Econometric Policy Evaluation: A Critique, In Brunner, K.; Meltzer, A. (eds.) The Phillips Curve and Labor Markets. Carnegie-Rochester Conference Series on Public Policy, American Elsevier, New York, 19-46

Lucas, R.; Sargent, T. (1979) After Keynesian macroeconomics, Quarterly Review, Federal Reserve Bank of Minneapolis, 3, 1-16

Nordhaus, W. (1975) The Political Business Cycle, Review of Economic Studies, 42, 169-190

North, D. (1990) Institutions, Institutional Change and Economic Performance, Cambridge University Press, Cambridge

Persson T.; Svensson, L. (1989) Why a Stubborn Conservative Would Run a Deficit: Policy with Time-Inconsistent Preferences, Quarterly Journal of Economics, 104, 325 - 345

Persson, T.; Tabellini, G. (1990) Macroeconomic Policy, Credibility, and Politics, Harwood Academic Publishers, Chur, Switzerland

Persson, T.; Tabellini, G. (1994) Is Inequality Harmful for Growth? Theory and Evidence, NBER Working Paper, 3599

Praščević, A. (2012) The Role of Government in Overcoming the Effects of Global Economic Crisis in Serbia - Obstacles from the Past, Montenegrin Journal of Economics, 8 (1), 137-155.

Praščević, A. (2014) Velike debate u makroekonomiji: kraj radikalnog antikejnzijanizma?, In Jovanović Gavrilović, B. et al (ed.), Ekonomska politika i razvoj, Ekonomski fakultet, Beograd, 9-39

Rogoff, K. (1985) The Optimal Degree of Commitment to an Intermediate Monetary Target, Quartely Journal of Economics, 100(4), 1169-1189

Rogoff K. (1990) Equilibrium political budget cycles, American Economic Review, 80, 21-36

Rogoff, K.; Sibert, A. (1988) Elections and Macroeconomic Policy Cycles, Review of Economic Studies, $55,1-16$

Shi, M.; Svensson, J. (2002) Political Budget Cycles in Developed and Developing Countries, Working paper, IIES, Stokholm University 
Shi, M.; Svensson, J. (2006) Political budget cycles: Do they differ across countries and why?, Journal of Public Economics, 90, 1367-1389

Svensson, L. E.O. (1995) Optimal Inflation Targets, 'Conservative' Central Banks, and Linear Inflation Contracts, NBER Working Papers 5251, National Bureau of Economic Research, Inc.

Treisman, D.; Gimpelson, V. (2001) Political business cycles and Russian elections, or the manipulations of' Chudar', British Journal of Political Science, 225-246,

Tufte E.R. (1978) Political control of the economy, Princeton University Press, Princeton

Turley G.; Luke, P. J. (2011) Transition Economics - Two Decades On, Routledge, London

Waller, C. J. (1992) A bargain model of partisan appointments to the central bank, Journal of Monetary Economics, 29 (3), 411-428

Walsh, C. (1995) Optimal Contracts for Central Bankers, American Economic Review, 85(1), 150-167 